\title{
ZASTOSOWANIE METOD GIS W ANALIZIE STRUKTURY PRZESTRZENNEJ OBSZARÓW WIEJSKICH GMINY SŁAWNO W POWIECIE OPOCZYŃSKIM
}

\begin{abstract}
Celem pracy jest przedstawienie możliwości wykorzystania narzędzi GIS w analizie struktury przestrzennej obszarów wiejskich. Badania przeprowadzono w 34 wsiach gminy Sławno położonej w powiecie opoczyńskim, województwo łódzkie. W pracy przeprowadzono analizy dotyczące struktury władania gruntami, analizy użytkowania gruntami, jak również analizę rozdrobnienia gruntów gospodarstw indywidualnych. Otrzymane wyniki pozwolą określić stan struktury przestrzennej obszarów wiejskich Polski centralnej.
\end{abstract}

Słowa kluczowe: geodezja rolna, scalenia gruntów, struktura przestrzenna, GIS

\section{Wprowadzenie}

Każdy region Polski charakteryzuje się cechami, które mają bezpośredni wpływ na tempo i rozwój społeczno-gospodarczy [1]. Województwo łódzkie charakteryzuje się gorszymi niż przeciętne w kraju warunkami przyrodniczymi dla rozwoju rolnictwa, ale równocześnie ta forma działalności stanowi obok przemysłu główną specjalizację gospodarczą regionu. W województwie dominują małe i bardzo małe gospodarstwa o niskiej produktywności. Obszary wiejskie charakteryzują się niedostateczną aktywnością gospodarczą i słabą aktywizacją społeczną, niekorzystną sytuacją w zakresie wyposażenia w urządzenia sieciowe czy utrudnioną dostępnością do usług społecznych. Dlatego dla obszarów wiejskich i dominującego na nich rolnictwa tak ważna jest restrukturyzacja produkcji rolnej i podniesienie jej walorów jakościowych zmierzające do zwiększenia efektywności ekonomicznej, jak również poprawa warunków cywilizacyjnych mieszkańców.

\footnotetext{
${ }^{1}$ Autor do korespondencji / corresponding author: Przemysław Leń, Wyższa Szkoła InżynieryjnoEkonomiczna w Rzeszowie, ul. Miłocińska 40, 35-232 Rzeszów, tel. 178660430, plen@wsie.edu.pl

2 Ewa Głowienka, Politechnika Świętokrzyska, Wydział Inżynierii Środowiska, Geomatyki i Energetyki, Al. Tysiąclecia Państwa Polskiego 7, 25-314 Kielce, eglo@interia.pl
} 
Specyfika gospodarstw rolnych województwa łódzkiego oraz uwarunkowania środowiska wskazują na możliwość zbudowania silnego sektora rolniczego zorientowanego na ekorolnictwo, co poprawi sytuację ekologiczną województwa [2]. Użytki rolne badanego obszaru charakteryzują się dużym rozdrobnieniem, niewielką powierzchnią działek, często o niekształtnych formach. Układ sieci dróg bezpośredniej obsługi użytków rolnych, pochodzący z okresu osadnictwa wsi na tym terenie nie zapewnia dostępu drogowego do nich z siedliska. Natomiast stan techniczny tych dróg utrudnia, a niejednokrotnie uniemożliwia dostęp do działek maszyn rolniczych. Produkcja rolna $w$ tych warunkach obciążona jest nadmiernymi kosztami, a rozwój gospodarstw rolnych jest utrudniony. Występujące wadliwości w rolniczej przestrzeni produkcyjnej można eliminować poprzez realizację kompleksowych prac scalenia i wymiany gruntów. Prace te maja na celu poprawę struktury przestrzennej obszarów wiejskich [3].

Proces scalania gruntów odgrywa istotną rolę w urządzaniu przestrzeni wiejskich, ponieważ stymuluje rozwój funkcji pełnionych przez te obszary m.in. w sferze gospodarczej, społecznej czy środowiskowej. Poprzez zmiany w strukturze własności i użytkowania daje możliwości wydzielenia obszarów funkcjonalno-przestrzennych, niwelując tym samym potencjalne konflikty przestrzenne, środowiskowe i społeczne. Korzystnie wpływa na rozwoju rolnictwa, w tym szczególnie produkcji ekologicznej oraz innych funkcji pozarolniczych. Scalanie gruntów wpisuje się w cel szczegółowy PROW 2014-2020, którym jest ,poprawa wyników gospodarczych wszystkich gospodarstw oraz ułatwianie restrukturyzacji i modernizacji gospodarstw, szczególnie z myśla o zwiększeniu uczestnictwa $w$ rynku i zorientowania na rynek, a także zróżnicowania produkcji rolnej”. Przeprowadzenie procesu scalenia ułatwia prowadzenie produkcji rolnej poprzez ograniczenie kosztów ponoszonych w gospodarstwie, otwiera drogę do wprowadzenia nowoczesnych technologii. Pomaga w racjonalnym wykorzystaniu zasobów ziemi uprawnej poprzez dostosowanie rozłogu gruntów i istniejącej infrastruktury do potrzeb gospodarstw [4].

Podjęcie prac przekształcających wadliwe układy gruntowe na całym obszarze jest niemożliwe ze względów technicznych jak i finansowych. Dlatego też prace scalenia i wymiany gruntów powinny być podejmowane w tych wsiach, w których występują najpilniejsze potrzeby. Wynika stąd konieczność oceny stopnia wadliwości struktury przestrzennej gruntów dla określenia zapotrzebowania na prace scalenia i wymiany gruntów, a przede wszystkim ustalenia kolejności ich wykonywania[1]. Aby dokonać tej oceny koniecznym jest przeprowadzenie szeregu analiz charakteryzujących strukturę przestrzenną badanego obszaru. Biorąc pod uwagę charakter analiz oraz zestaw danych potrzebny do ich wykonania niewątpliwie bardzo skutecznym sposobem uzyskania szybkiego i dokładnego wyniku w postaci mapy i tabel, może być zastosowanie narzędzi Geograficznych Systemów Informacji/Systemów Informacji Przestrzennej (GIS/SIP). Dlatego też w niniejszym artykule przedstawiono rezultaty analiz dotyczących struktury władania, użytkowania, jak również rozdrobnienia gruntów gospodarstw indywidualnych przeprowadzone za pomocą metod GIS. 
Do przeprowadzenia analiz wykorzystano dane EGiB pozyskane w Powiatowym Ośrodku Dokumentacji Geodezyjnej i Kartograficznej w Opocznie. Dane ewidencyjne zostały zapisane w formacie ESRI SHAPE. Do badania struktury przestrzennej analizowanego obszaru zastosowano narzędzia Systemów Informacji Przestrzennej (SIP/GIS) zaimplentowane w oprogramowaniu Geomedia Professional oraz QGIS. Obydwa programy wykorzystują dane przestrzennoatrybutowe do zbudowania odpowiednich zapytań do bazy danych, umożliwiających wyselekcjonowanie obiektów o określonych cechach lub relacjach przestrzennych. Wybór oprogramowania miał na celu sprawdzenie funkcjonalności darmowego oprogramowania QGIS w zadaniach analiz struktury przestrzennej nakierowanej na prace scaleniowe, w stosunku do profesjonalnego oprogramowania Geomedia.

Do określenia stosunków prawno-własnościowych oraz sposobu użytkowania posłużyły dane opisowe zapisane w bazie jako odpowiednie atrybuty, dla których przygotowane zostały zapytania typy SQL. Na podstawie danych wektorowych dla wyselekcjonowanych grup obliczona została powierzchnia w poszczególnych obrębach gminy Sławno. W trakcie analiz wykorzystano narzędzia łączenia danych zewnętrznych zapisanych w arkuszach kalkulacyjnych Excel. Takie operacje pozwoliły na wzbogacenie bazy danych o dodatkowe atrybutowe wykorzystane do analizy władania i użytkowania. W przypadku analizy rozdrobnienia wykorzystano typowe zapytania przestrzenne umożliwiające obliczenie powierzchni wszystkich działek, natomiast automatyczne narzędzia do tworzenia map tematycznych i klasyfikowania umożliwiły przyporządkowanie ich do odpowiedniej grupy.

\section{Analiza badanego obiektu}

Gmina Sławno położona jest we wschodniej części województwa łódzkiego, na Wzgórzach Opoczyńskich będących północnym obszarem Wyżyny Kielecko-Sandomierskiej, w odległości $80 \mathrm{~km}$ od Łodzi, $20 \mathrm{~km}$ od Tomaszowa Mazowieckiego oraz $10 \mathrm{~km}$ od Opoczna. Zajmuje powierzchnię $128 \mathrm{~km}^{2}$, co klasyfikuje ją w grupie gmin średnich pod względem powierzchni. Graniczy od północy z gminą Tomaszów Mazowiecki i Inowłódz, od wschodu z gminą Opoczno, od południa z gminami Białaczów i Paradyż, od zachodu z Mniszkowem. Teren gminy zamieszkuje 7.872 mieszkańców w 33 sołectwach. Przez obszar gminy przebiega droga krajowa Nr 12 relacji Piotrków TrybunalskiRadom, droga wojewódzka Nr 713 Opoczno-Łódź [5]. Położenie gminy Sławno ilustruje rys. 1. 


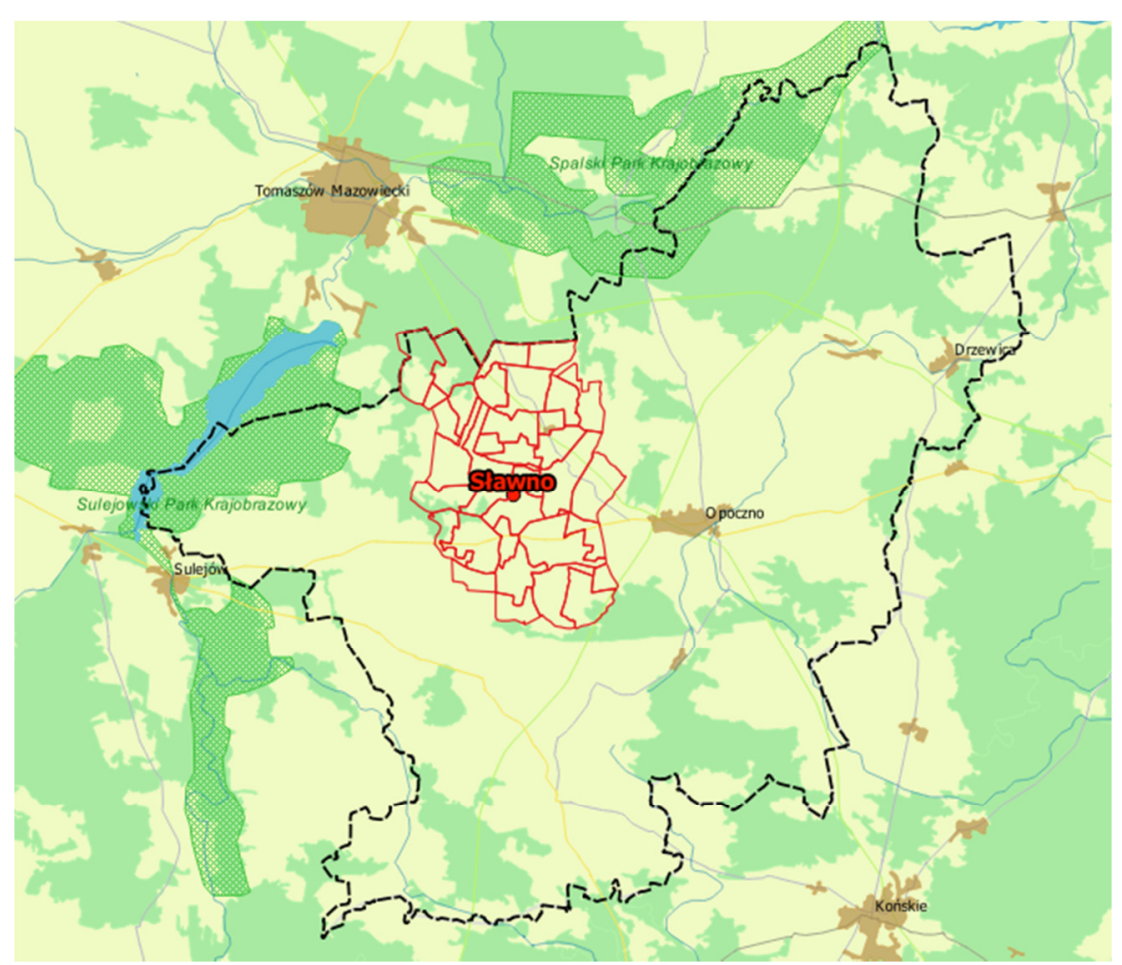

Rys. 1. Położenie gminy Sławno

Fig. 1. Localization of community

\section{Analiza struktury przestrzennej obszarów wiejskich}

\subsection{Stosunki prawno-własnościowe do gruntów}

Jak wynika $\mathrm{z}$ danych tabeli 1 , dominującym sektorem jest indywidualna własność do gruntów, która stanowi 78.2\% ogólnej powierzchni badanego obszaru. W poszczególnych obrębach jest ona różna. W 17 obrębach procentowa powierzchnia gruntów indywidualnych przekracza $90.0 \%$ a najwyższym odsetkiem charakteryzują się wsie Ludwninów (98.2\%), Wincentów (96.4\%), Dąbrowa (96.3\%), Popławy (96.2\%).

Jak wynika z przeprowadzonych badań w trzech wsiach procentowy udział gruntów indywidualnych jest niewielki i stanowi: we wsi Olszewice $(1.2 \%)$, Grudzień Las (25.1\%) oraz Unewal (32.4\%).

Jak wynika z przeprowadzonych badań Lasy Państwowe stanowią 9.6\% ogólnej powierzchni badanego terenu. Grunty badanego sektora występują w 20 obrębach, co stanowi $58.8 \%$ badanych wsi (rys. 2). Ich procentowy udział waha się od $0.1 \%$ we wsiach Zachorzów, Kolonia Grudzień i Popławy do $74.8 \%$ we wsi Olszewice. 
Tabela 1. Stosunki prawno-własnościowe na badanym terenie

Table 1. Legal and ownership relations in the site

\begin{tabular}{|c|c|c|c|c|c|c|c|c|c|c|}
\hline \multirow[t]{2}{*}{ Lp. } & \multirow[t]{2}{*}{ Nazwa obrębu } & \multirow[t]{2}{*}{$\begin{array}{l}\text { Powierzchnia } \\
\text { ogólna }\end{array}$} & \multicolumn{2}{|c|}{$\begin{array}{l}\text { Udział gruntów } \\
\text { gospodarstw } \\
\text { indywidualnych }\end{array}$} & \multicolumn{2}{|c|}{$\begin{array}{l}\text { Udział Lasów } \\
\text { Państwowych }\end{array}$} & \multicolumn{2}{|c|}{$\begin{array}{l}\text { Udział gruntów } \\
\text { Agencji Własności } \\
\text { Rolnej Skarbu } \\
\text { Państwa }\end{array}$} & \multicolumn{2}{|c|}{$\begin{array}{l}\text { Udział gruntów } \\
\text { gminnych }\end{array}$} \\
\hline & & & Pow. & $\%$ & Pow. & $\%$ & Pow. & $\%$ & Pow. & $\%$ \\
\hline 1 & Antoninów & 408,7 & 294,5 & 72,1 & 12,7 & 3,1 & 8,5 & 2,1 & 9,5 & 2,3 \\
\hline 2 & Antoniówka & 346,2 & 317,0 & 91,6 & 0,0 & 0,0 & 20,2 & 5,9 & 0,6 & 0,2 \\
\hline 3 & Bratków & 288,3 & 244,6 & 84,8 & 14,1 & 4,9 & 18,5 & 6,4 & 8,1 & 2,8 \\
\hline 4 & Celestynów & 95,0 & 76,3 & 80,4 & 0,0 & 0,0 & 6,9 & 7,2 & 1,4 & 1,5 \\
\hline 5 & Dąbrowa & 280,0 & 269,5 & 96,3 & 0,0 & 0,0 & 2,1 & 0,7 & 6,0 & 2,1 \\
\hline 6 & Dąbrówka & 370,3 & 348,3 & 94,1 & 6,0 & 1,6 & 9,9 & 2,7 & 1,1 & 0,3 \\
\hline 7 & Gawrony & 607,6 & 568,0 & 93,5 & 0,0 & 0,0 & 18,9 & 3,1 & 13,1 & 2,2 \\
\hline 8 & Grążowice & 264,7 & 252,1 & 95,2 & 0,0 & 0,0 & 4,2 & 1,6 & 6,2 & 2,3 \\
\hline 9 & $\begin{array}{l}\text { Kolonia } \\
\text { Grudzień }\end{array}$ & 209,3 & 133,1 & 63,6 & 0,2 & 0,1 & 2,0 & 1,0 & 1,3 & 0,6 \\
\hline 10 & Grudzień las & 247,5 & 62,2 & 25,1 & 45,5 & 18,4 & 15,2 & 6,2 & 6,2 & 2,5 \\
\hline 11 & Józefów & 136,4 & 127,4 & 93,4 & 0,0 & 0,0 & 1,6 & 1,2 & 0,0 & 0,0 \\
\hline 12 & Kamień & 550,8 & 447,5 & 81,3 & 44,1 & 8,0 & 25,4 & 4,6 & 27,0 & 4,9 \\
\hline 13 & Kamilówka & 259,2 & 224,0 & 86,4 & 24,1 & 9,3 & 3,7 & 1,4 & 3,9 & 1,5 \\
\hline 14 & Kozenin & 584,2 & 547,0 & 93,6 & 1,1 & 0,2 & 10,8 & 1,9 & 10,4 & 1,8 \\
\hline 15 & Kunice & 683,8 & 623,2 & 91,1 & 8,5 & 1,3 & 26,1 & 3,8 & 3,8 & 0,6 \\
\hline 16 & Ludwinów & 135,1 & 132,7 & 98,2 & 0,0 & 0,0 & 2,3 & 1,7 & 0,1 & 0,1 \\
\hline 17 & Olszewice & 559,2 & 6,6 & 1,2 & 418,2 & 74,8 & 34,2 & 6,1 & 1,7 & 0,3 \\
\hline 18 & Olszowiec & 588,1 & 516,7 & 87,9 & 0,0 & 0,0 & 11,2 & 1,9 & 4,8 & 0,8 \\
\hline 19 & Ostrożyna & 252,1 & 240,8 & 95,5 & 0,0 & 0,0 & 2,0 & 0,8 & 1,5 & 0,6 \\
\hline 20 & Owadów & 195,5 & 148,3 & 75,9 & 0,0 & 0,0 & 4,0 & 2,1 & 2,8 & 1,4 \\
\hline 21 & Popławy & 232,0 & 223,2 & 96,2 & 0,3 & 0,1 & 1,6 & 0,7 & 4,5 & 2,0 \\
\hline 22 & $\begin{array}{l}\text { Prymusowa } \\
\text { Wola }\end{array}$ & 755,3 & 467,3 & 61,9 & 245,6 & 32,5 & 11,2 & 1,5 & 12,9 & 1,7 \\
\hline 23 & Janków Psary & 425,4 & 407,9 & 95,9 & 0,0 & 0,0 & 5,2 & 1,2 & 6,8 & 1,6 \\
\hline 24 & Sepno Radonia & 410,2 & 270,8 & 66,0 & 43,2 & 10,5 & 12,9 & 3,2 & 2,9 & 0,7 \\
\hline 25 & Sławno & 439,3 & 391,4 & 89,1 & 0,8 & 0,2 & 7,9 & 1,8 & 10,5 & 2,4 \\
\hline 26 & $\begin{array}{l}\text { Sławno } \\
\text { Kolonia }\end{array}$ & 442,7 & 366,3 & 82,8 & 15,0 & 3,4 & 8,9 & 2,0 & 10,6 & 2,4 \\
\hline 27 & Szadkowice & 149,1 & 134,6 & 90,3 & 0,0 & 0,0 & 8,6 & 5,8 & 1,7 & 1,1 \\
\hline 28 & Tomaszówek & 275,4 & 259,8 & 94,3 & 0,0 & 0,0 & 6,0 & 2,2 & 0,5 & 0,2 \\
\hline 29 & Trojanów & 313,9 & 223,2 & 71,1 & 72,7 & 23,2 & 11,9 & 3,8 & 1,9 & 0,6 \\
\hline 30 & Unewal & 638,5 & 207,0 & 32,4 & 286,9 & 44,9 & 4,1 & 0,6 & 36,4 & 5,7 \\
\hline 31 & Wincentów & 303,1 & 292,0 & 96,4 & 0,0 & 0,0 & 5,6 & 1,8 & 0,4 & 0,1 \\
\hline 32 & Wygnanów & 454,6 & 315,3 & 69,4 & 1,6 & 0,4 & 5,8 & 1,3 & 7,1 & 1,6 \\
\hline 33 & Zachorzów & 535,3 & 505,5 & 94,4 & 0,7 & 0,1 & 7,0 & 1,3 & 15,3 & 2,9 \\
\hline 34 & $\begin{array}{c}\text { Kolonia } \\
\text { Zachorzów }\end{array}$ & 512,0 & 487,7 & 95,2 & 1,2 & 0,2 & 13,5 & 2,6 & 7,2 & 1,4 \\
\hline & Razem: & 12948,8 & 10131,9 & 78,2 & 1242,5 & 9,6 & 337,8 & 2,6 & 228,2 & 1,8 \\
\hline
\end{tabular}




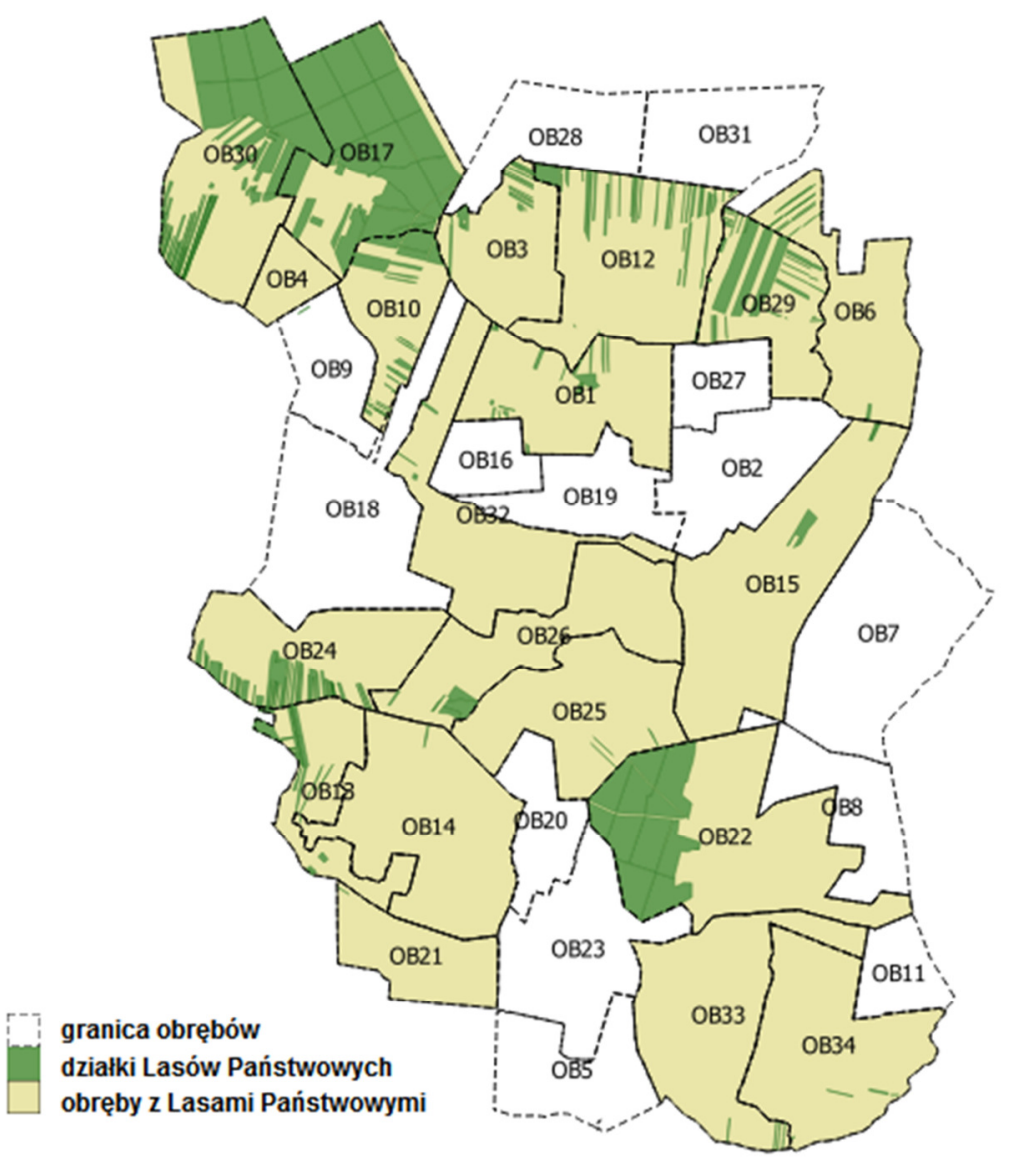

Rys.2. Przestrzenne rozmieszczenie gruntów Lasów Państwowych

Fig.2. Spatial distribution of land National Forests

Równie duże zróżnicowanie wsi zaobserwowano dla gruntów Agencji Nieruchomości Rolnej Skarbu Państwa, które kształtują się od 0.6\% we wsi Unewal do $7.2 \%$ we wsi Celestynów oraz w gruntach gminnych, których ogólna powierzchnia stanowi $1.8 \%$ ogólnej powierzchni badanego terenu i waha się ona od $0.1 \%$ we wsiach Wincentów, Ludwinów do $5.7 \%$ we wsi Unewal. We wsi Józefów grunty gminne nie występują.

Reasumując analizę stosunków prawno-własnościowych gruntów należy stwierdzić dominujący udział sektora indywidualnego zajmujący powyżej 78.0\% powierzchni w badanych 34 wsiach. Grunty Lasów Państwowych stanowią 9.6\% ogólnej powierzchni i występują one w 20 badanych obrębach. We wsi Olszewice stanowią one prawie 75\%. Udział gruntów Agencji Własności Rolnej Skarbu Państwa stanowi $2.6 \%$, zaś udział gruntów gminnych stanowi zaledwie $1.6 \%$ ogólnej powierzchni gminy Sławno. 


\subsection{Struktura użytków gruntowych}

Na sposób użytkowania gruntów w badanych wsiach decydujący wpływ miała indywidualna własność gruntów. Wielkość tej formy jak wykazano w przeprowadzonej analizie władania stanowi podstawową formę zagospodarowania powierzchni badanego obszaru. Ten fakt sprawił, że od chwili osiedlenia się na tym terenie, ludność przysposabiała go sobie dla celów egzystencjonalnych.

Jak wynika $z$ danych tabeli 2 najwyższy odsetek na badanym terenie stanowią grunty orne, których powierzchnia stanowi $61.3 \%$ ogólnej powierzchni gmi-

Tabela 2. Struktura użytków gruntowych

Table 2. Structure of land use

\begin{tabular}{|c|c|c|c|c|c|c|c|c|c|c|c|c|c|c|}
\hline \multirow[t]{2}{*}{ Lp. } & \multirow[t]{2}{*}{ Nazwa obrębu } & \multirow{2}{*}{$\begin{array}{c}\text { Ogólna } \\
\text { powierz } \\
\text { chnia } \\
\text { obrębu }\end{array}$} & \multicolumn{2}{|c|}{ Grunty orne } & \multicolumn{2}{|c|}{ Lasy } & \multicolumn{2}{|c|}{ Pastwiska } & \multicolumn{2}{|c|}{ Łąki } & \multicolumn{2}{|c|}{$\begin{array}{c}\text { Tereny rolne } \\
\text { budowlane }\end{array}$} & \multicolumn{2}{|c|}{$\begin{array}{c}\text { Tereny } \\
\text { komunika } \\
\text { cyjne }\end{array}$} \\
\hline & & & Pow. & $\%$ & Pow. & $\%$ & Pow. & $\%$ & Pow. & $\%$ & Pow. & $\%$ & Pow. & $\%$ \\
\hline 1 & Antoninów & 408,7 & 263,8 & 64,5 & 73,8 & 18,1 & 38,2 & 9,4 & 10,6 & 2,6 & 9,0 & 2,2 & 4,3 & 1,1 \\
\hline 2 & Antoniówka & 346,2 & 227,2 & 65,6 & 44,4 & 12,8 & 28,4 & 8,2 & 22,7 & 6,6 & 7,3 & 2,1 & 6,3 & 1,8 \\
\hline 3 & Bratków & 288,3 & 188,5 & 65,4 & 45,2 & 15,7 & 7,0 & 2,4 & 18,7 & 6,5 & 7,9 & 2,7 & 4,3 & 1,5 \\
\hline 4 & Celestynów & 95,0 & 52,7 & 55,5 & 13,7 & 14,4 & 7,6 & 8,0 & 4,9 & 5,1 & 4,0 & 4,2 & 1,4 & 1,5 \\
\hline 5 & Dąbrowa & 280,0 & 225,4 & 80,5 & 15,6 & 5,6 & 10,1 & 3,6 & 15,3 & 5,5 & 5,1 & 1,8 & 4,3 & 1,6 \\
\hline 6 & Dąbrówka & 370,3 & 218,0 & 58,9 & 78,0 & 21,1 & 20,0 & 5,4 & 27,8 & 7,5 & 5,8 & 1,6 & 8,1 & 2,2 \\
\hline 7 & Gawrony & 607,6 & 418,2 & 68,8 & 15,3 & 2,5 & 114,3 & 18,8 & 0,0 & 0,0 & 18,4 & 3,0 & 12,7 & 2,1 \\
\hline 8 & Grążowice & 264,7 & 211,7 & 80,0 & 10,9 & 4,1 & 17,5 & 6,6 & 3,9 & 1,5 & 8,1 & 3,1 & 6,5 & 2,4 \\
\hline 9 & $\begin{array}{c}\text { Kolonia Gru- } \\
\text { dzień }\end{array}$ & 209,3 & 165,6 & 79,1 & 15,3 & 7,3 & 9,9 & 4,7 & 0,0 & 0,0 & 4,8 & 2,3 & 4,2 & 2,0 \\
\hline 10 & Grudzień las & 247,5 & 104,6 & 42,3 & 101,4 & 41,0 & 21,2 & 8,6 & 0,0 & 0,0 & 3,2 & 1,3 & 3,6 & 1,5 \\
\hline 11 & Józefów & 136,4 & 113,9 & 83,5 & 1,9 & 1,4 & 7,6 & 5,6 & 6,0 & 4,4 & 3,6 & 2,7 & 1,9 & 1,4 \\
\hline 12 & Kamień & 550,8 & 301,2 & 54,7 & 152,4 & 27,7 & 46,7 & 8,5 & 11,8 & 2,1 & 9,5 & 1,7 & 8,6 & 1,6 \\
\hline 13 & Kamilówka & 259,2 & 164,3 & 63,4 & 77,4 & 29,9 & 6,9 & 2,7 & 0,0 & 0,0 & 1,9 & 0,7 & 4,7 & 1,8 \\
\hline 14 & Kozenin & 584,2 & 426,1 & 72,9 & 51,8 & 8,9 & 30,4 & 5,2 & 30,6 & 5,2 & 14,4 & 2,5 & 22,1 & 3,8 \\
\hline 15 & Kunice & 683,8 & 465,1 & 68,0 & 38,5 & 5,6 & 111,8 & 16,3 & 7,4 & 1,1 & 15,1 & 2,2 & 15,2 & 2,2 \\
\hline 16 & Ludwinów & 135,1 & 97,6 & 72,2 & 9,2 & 6,8 & 21,0 & 15,5 & 0,0 & 0,0 & 3,1 & 2,3 & 2,3 & 1,7 \\
\hline 17 & Olszewice & 559,2 & 70,5 & 12,6 & 430,3 & 76,9 & 6,9 & 1,2 & 0,0 & 0,0 & 1,4 & 0,2 & 5,9 & 1,1 \\
\hline 18 & Olszowiec & 588,1 & 449,4 & 76,4 & 84,0 & 14,3 & 25,2 & 4,3 & 1,3 & 0,2 & 10,8 & 1,8 & 15,6 & 2,6 \\
\hline 19 & Ostrożyna & 252,1 & 201,2 & 79,8 & 3,0 & 1,2 & 28,2 & 11,2 & 3,2 & 1,3 & 5,6 & 2,2 & 4,3 & 1,7 \\
\hline 20 & Owadów & 195,5 & 140,6 & 71,9 & 10,2 & 5,2 & 19,9 & 10,2 & 0,0 & 0,0 & 5,7 & 2,9 & 5,3 & 2,7 \\
\hline 21 & Popławy & 232,0 & 175,5 & 75,6 & 9,6 & 4,1 & 15,0 & 6,5 & 14,8 & 6,4 & 5,7 & 2,4 & 4,4 & 1,9 \\
\hline 22 & $\begin{array}{c}\text { Prymusowa } \\
\text { Wola } \\
\end{array}$ & 755,3 & 391,8 & 51,9 & 246,0 & 32,6 & 47,7 & 6,3 & 6,8 & 0,9 & 13,6 & 1,8 & 24,6 & 3,3 \\
\hline 23 & Janków Psary & 425,4 & 300,0 & 70,5 & 29,0 & 6,8 & 41,3 & 9,7 & 22,2 & 5,2 & 12,5 & 2,9 & 11,1 & 2,6 \\
\hline 24 & Sepno Radonia & 410,2 & 276,0 & 67,3 & 98,2 & 23,9 & 14,8 & 3,6 & 0,0 & 0,0 & 5,5 & 1,3 & 12,4 & 3,0 \\
\hline 25 & Sławno & 439,3 & 259,6 & 59,1 & 68,9 & 15,7 & 60,6 & 13,8 & 13,9 & 3,2 & 12,3 & 2,8 & 9,9 & 2,3 \\
\hline 26 & Sławno Kolonia & 442,7 & 270,3 & 61,1 & 49,6 & 11,2 & 34,1 & 7,7 & 10,7 & 2,4 & 13,8 & 3,1 & 10,7 & 2,4 \\
\hline 27 & Szadkowice & 149,1 & 91,1 & 61,1 & 3,2 & 2,2 & 29,1 & 19,5 & 0,4 & 0,3 & 9,0 & 6,0 & 4,3 & 2,9 \\
\hline 28 & Tomaszówek & 275,4 & 179,1 & 65,0 & 25,4 & 9,2 & 19,9 & 7,2 & 28,0 & 10,2 & 9,4 & 3,4 & 4,2 & 1,5 \\
\hline 29 & Trojanów & 313,9 & 130,7 & 41,6 & 143,7 & 45,8 & 13,6 & 4,3 & 13,5 & 4,3 & 3,6 & 1,2 & 6,4 & 2,0 \\
\hline 30 & Unewal & 638,5 & 76,3 & 12,0 & 386,1 & 60,5 & 23,7 & 3,7 & 11,3 & 1,8 & 9,7 & 1,5 & 6,4 & 1,0 \\
\hline 31 & Wincentów & 303,1 & 193,7 & 63,9 & 25,6 & 8,5 & 54,3 & 17,9 & 8,1 & 2,7 & 9,0 & 3,0 & 5,5 & 1,8 \\
\hline 32 & Wygnanów & 454,6 & 324,1 & 71,3 & 49,6 & 10,9 & 19,0 & 4,2 & 15,8 & 3,5 & 15,2 & 3,3 & 10,9 & 2,4 \\
\hline 33 & Zachorzów & 535,3 & 419,8 & 78,4 & 41,7 & 7,8 & 25,9 & 4,8 & 12,8 & 2,4 & 13,0 & 2,4 & 12,3 & 2,3 \\
\hline 34 & \begin{tabular}{|c|}
$\begin{array}{c}\text { Kolonia Zacho- } \\
\text { rzów }\end{array}$ \\
\end{tabular} & 512,0 & 344,4 & 67,3 & 65,6 & 12,8 & 20,0 & 3,9 & 47,8 & 9,3 & 10,6 & 2,1 & 9,5 & 1,8 \\
\hline & Razem: & 12948,8 & 7937,7 & 61,3 & 2514,4 & 19,4 & 997,8 & 7,7 & 370,4 & 2,9 & 287,5 & 2,2 & 274,2 & 2,1 \\
\hline
\end{tabular}


ny Sławno i waha się ona od $12.0 \%$ we wsi Unewal do $83.5 \%$ we wsi Józefów. W 30 wsiach procentowy udział gruntów ornych stanowi ponad $50.0 \%$ powierzchni poszczególnych wsi. Przeprowadzone badania wykazały także, iż lasy stanowią $19.4 \%$ ogólnej powierzchni wsi. Przy czym, we wsi Olszewice stanowią one aż 76.9\% powierzchni tego obrębu. Natomiast w przypadku obrębów 11 i 19 (Józefów i Ostrożyna) stanowią niewiele ponad 1.0\% ich powierzchni. Kolejnym użytkiem pod względem wielkości powierzchni są pastwiska, które stanowią 7.7\% ogólnej powierzchni badanej gminy. Ich powierzchnia waha się od $1.2 \%$ we wsi Olszewice do $19.5 \%$ we wsi Szadkowice. Użytki typu „Łąki” stanowią $2.9 \%$ powierzchni całkowitej gminy Sławno. Ich powierzchnia waha się od $0.2 \%$ we wsi Olszowiec do $10.2 \%$ we wsi Tomaszówek. Ponadto, przeprowadzone analizy wykazały, iż bardzo niewielki udział w powierzchni całkowitej badanego obszaru gminy stanowią tereny rolne budowlane i tereny komunikacyjne (odpowiednio $2.2 \%$ i $2.1 \%$ ).

\subsection{Rozdrobnienie gruntów gospodarstw indywidualnych}

\subsubsection{Rozdrobnienie ze względu na liczbę działek ewidencyjnych}

Jak wynika z danych tabeli $3 \mathrm{w}$ gminie Sławno, 22.6\% wszystkich działek, to działki, których powierzchnia nie przekracza 0.10 ha. Jednak liczba działek o tak małej powierzchni, w poszczególnych wsiach jest bardzo zróżnicowana. Waha się ona $1.1 . \%$ we wsi Popławy aż do $54.2 \%$ we wsi Grążowice.

$\mathrm{W}$ przedziale powierzchni $0.11 \div 0.30 \mathrm{ha}$, w badanej gminie znajduje się 7846 działek, co stanowi 32.9\% ogólnej liczby działek. W poszczególnych wsiach liczba działek w analizowanym przedziale jest różna. Waha się ona od $13.9 \%$ we wsi Popławy do $43.3 \%$ we wsi Szadkowice. W przedziale od $0.31 \div 0.60$ liczba działek wynosi 5467 , co stanowi $22.9 \%$ ogólnej liczby działek w gminie Sławno. Ich procentowy udział waha się od $10.8 \%$ we wsi Grążowice do $43.8 \%$ we wsi Celestynów. Należy zaznaczyć, że jedynie we wsi Olszewice nie odnotowano działek w badanym przedziale powierzchniowym. Na podstawie analizy przedziału od 0.61-1.0ha uzyskano 2817 działek ewidencyjnych, co stanowi $11.8 \%$ ogólnej powierzchni gminy. Procentowy udział $\mathrm{w}$ wydzielonym przedziale waha się od $3.1 \%$ we wsi Owadów do $25.1 \%$ we wsi Popławy. Działek powyżej 1.01ha odnotowano 2354, co stanowi $9.9 \%$ ogólnej powierzchni badanego terenu. Procentowy udział tych działek waha się od $1.5 \%$ we wsi Ostrożyna do $32.2 \%$ we wsi Popławy. 
Tabela 3. Rozdrobnienie działek ze względu na ich liczbę

Table 3. Fragmentation of farmland due to their number

\begin{tabular}{|c|c|c|c|c|c|c|c|c|c|c|c|c|}
\hline \multirow{3}{*}{ Lp. } & \multirow{3}{*}{ Nazwa obrębu } & \multirow{3}{*}{$\begin{array}{l}\text { Ogólna } \\
\text { liczba } \\
\text { działek }\end{array}$} & \multicolumn{10}{|c|}{ Przedziały powierzchniowe } \\
\hline & & & \multicolumn{2}{|c|}{$0 \div 0.10$ ha } & \multicolumn{2}{|c|}{$0.11 \div 0.30$ ha } & \multicolumn{2}{|c|}{$0.31 \div 0.60 \mathrm{ha}$} & \multicolumn{2}{|c|}{$0.61 \div 1,00$ ha } & \multicolumn{2}{|c|}{$>1.01 \mathrm{ha}$} \\
\hline & & & Liczba & $\%$ & Liczba & $\%$ & Liczba & $\%$ & Liczba & $\%$ & Liczba & $\%$ \\
\hline 1 & Antoninów & 678 & 137 & 20,2 & 205 & 30,2 & 164 & 24,2 & 110 & 16,2 & 62 & 9,1 \\
\hline 2 & Antoniówka & 847 & 161 & 19,0 & 288 & 34,0 & 248 & 29,3 & 104 & 12,3 & 46 & 5,4 \\
\hline 3 & Bratków & 545 & 123 & 22,6 & 200 & 36,7 & 114 & 20,9 & 48 & 8,8 & 60 & 11,0 \\
\hline 4 & Celestynów & 153 & 12 & 7,8 & 36 & 23,5 & 67 & 43,8 & 23 & 15,0 & 15 & 9,8 \\
\hline 5 & Dąbrowa & 756 & 147 & 19,4 & 292 & 38,6 & 171 & 22,6 & 110 & 14,6 & 36 & 4,8 \\
\hline 6 & Dąbrówka & 764 & 220 & 28,8 & 182 & 23,8 & 163 & 21,3 & 106 & 13,9 & 93 & 12,2 \\
\hline 7 & Gawrony & 1726 & 385 & 22,3 & 641 & 37,1 & 453 & 26,2 & 176 & 10,2 & 71 & 4,1 \\
\hline 8 & Grążowice & 1180 & 639 & 54,2 & 301 & 25,5 & 128 & 10,8 & 71 & 6,0 & 41 & 3,5 \\
\hline 9 & $\begin{array}{c}\text { Kolonia } \\
\text { Grudzień }\end{array}$ & 323 & 38 & 11,8 & 110 & 34,1 & 105 & 32,5 & 44 & 13,6 & 26 & 8,0 \\
\hline 10 & Grudzień Las & 238 & 92 & 38,7 & 83 & 34,9 & 34 & 14,3 & 19 & 8,0 & 10 & 4,2 \\
\hline 11 & Józefów & 407 & 68 & 16,7 & 169 & 41,5 & 117 & 28,7 & 45 & 11,1 & 8 & 2,0 \\
\hline 12 & Kamień & 886 & 127 & 14,3 & 283 & 31,9 & 250 & 28,2 & 131 & 14,8 & 95 & 10,7 \\
\hline 13 & Kamilówka & 504 & 49 & 9,7 & 196 & 38,9 & 130 & 25,8 & 83 & 16,5 & 46 & 9,1 \\
\hline 14 & Kozenin & 862 & 64 & 7,4 & 208 & 24,1 & 260 & 30,2 & 159 & 18,4 & 171 & 19,8 \\
\hline 15 & Kunice & 1426 & 306 & 21,5 & 441 & 30,9 & 318 & 22,3 & 194 & 13,6 & 167 & 11,7 \\
\hline 16 & Ludwinów & 242 & 28 & 11,6 & 47 & 19,4 & 84 & 34,7 & 48 & 19,8 & 35 & 14,5 \\
\hline 17 & Olszewice & 17 & 5 & 29,4 & 7 & 41,2 & 0 & 0,0 & 4 & 23,5 & 1 & 5,9 \\
\hline 18 & Olszowiec & 835 & 88 & 10,5 & 234 & 28,0 & 208 & 24,9 & 148 & 17,7 & 157 & 18,8 \\
\hline 19 & Ostrożyna & 995 & 331 & 33,3 & 378 & 38,0 & 213 & 21,4 & 58 & 5,8 & 15 & 1,5 \\
\hline 20 & Owadów & 777 & 351 & 45,2 & 298 & 38,4 & 88 & 11,3 & 24 & 3,1 & 16 & 2,1 \\
\hline 21 & Popławy & 267 & 3 & 1,1 & 37 & 13,9 & 74 & 27,7 & 67 & 25,1 & 86 & 32,2 \\
\hline 22 & $\begin{array}{l}\text { Prymusowa } \\
\text { Wola }\end{array}$ & 1291 & 405 & 31,4 & 522 & 40,4 & 206 & 16,0 & 71 & 5,5 & 87 & 6,7 \\
\hline 23 & Janków Psary & 1211 & 285 & 23,5 & 458 & 37,8 & 285 & 23,5 & 120 & 9,9 & 63 & 5,2 \\
\hline 24 & Sepno Radonia & 324 & 6 & 1,9 & 51 & 15,7 & 98 & 30,2 & 67 & 20,7 & 102 & 31,5 \\
\hline 25 & Sławno & 847 & 150 & 17,7 & 313 & 37,0 & 189 & 22,3 & 94 & 11,1 & 101 & 11,9 \\
\hline 26 & $\begin{array}{c}\text { Sławno Kolo- } \\
\text { nia } \\
\end{array}$ & 465 & 26 & 5,6 & 108 & 23,2 & 128 & 27,5 & 88 & 18,9 & 115 & 24,7 \\
\hline 27 & Szadkowice & 436 & 84 & 19,3 & 189 & 43,3 & 95 & 21,8 & 50 & 11,5 & 18 & 4,1 \\
\hline 28 & Tomaszówek & 295 & 18 & 6,1 & 60 & 20,3 & 68 & 23,1 & 60 & 20,3 & 89 & 30,2 \\
\hline 29 & Trojanów & 488 & 58 & 11,9 & 172 & 35,2 & 147 & 30,1 & 61 & 12,5 & 50 & 10,2 \\
\hline 30 & Unewal & 580 & 138 & 23,8 & 233 & 40,2 & 123 & 21,2 & 43 & 7,4 & 43 & 7,4 \\
\hline 31 & Wincentów & 534 & 89 & 16,7 & 145 & 27,2 & 122 & 22,8 & 86 & 16,1 & 92 & 17,2 \\
\hline 32 & Wygnanów & 451 & 15 & 3,3 & 161 & 35,7 & 122 & 27,1 & 49 & 10,9 & 104 & 23,1 \\
\hline 33 & Zachorzów & 1309 & 355 & 27,1 & 438 & 33,5 & 265 & 20,2 & 143 & 10,9 & 108 & 8,3 \\
\hline 34 & $\begin{array}{c}\text { Kolonia } \\
\text { Zachorzów }\end{array}$ & 1212 & 384 & 31,7 & 360 & 29,7 & 230 & 19,0 & 113 & 9,3 & 125 & 10,3 \\
\hline & Razem: & 23871 & 5387 & 22,6 & 7846 & 32,9 & 5467 & 22,9 & 2817 & 11,8 & 2354 & 9,9 \\
\hline
\end{tabular}

\subsubsection{Rozdrobnienie ze względu na powierzchnię działek ewidencyjnych}

Jak wynika z przeprowadzonych badań (tabela 4) działki o powierzchni $0 \div 0.10$ ha wynoszą 279.5 ha, co stanowi $2.8 \%$ ogólnej powierzchni badanej gminy. Procentowy udział $\mathrm{w}$ badanym przedziale jest bardzo zróżnicowany, gdyż tylko w 2 wsiach procentowy udział przekracza 10.0\%: Owadów (13.0\%) i Grążowice (11.6\%), z kolei w 29 wsiach nie przekracza on $5.0 \%$ ogólnej po- 
wierzchni badanych wsi. W kolejnym przedziale $0.11 \div 0.30$ ha grunty zajmują 1485,1 ha, co stanowi $15.0 \%$ badanej gminy. Ich powierzchnia waha się od $3.7 \%$ we wsi Popławy do $36.9 \%$ we wsi Prymusowa Wola. W 11 obrębach procentowy udział wyniósł ponad $20.0 \%$.

W trzecim badanym przedziale powierzchniowym $0.31 \div 0.60$ powierzchnia działek stanowi $23.4 \%$ ogólnej powierzchni. I waha się ona od $11.2 \%$ we wsi Tomaszówek do $37.9 \%$ we wsi Józefów. W 8 wsiach gminy Sławno procentowy udział $\mathrm{W}$ wydzielonym przedziale przekroczył $30.0 \%$. W przedziale od $0.61 \div 1.00$ ha powierzchnia działek wyniosła 2150.8 ha, co stanowi $21.7 \%$ ogólnej powierzchni gminy. Procentowy udział waha się od $12.1 \%$ we wsi Owadów aż do $54.4 \%$ we wsi Olszewice. W ostatnim badanym przedziale powyżej 1.01 ha, powierzchnia działek gruntów gospodarstw indywidualnych wyniosła 3684.4 ha, co stanowi $37.1 \%$ całkowitej powierzchnie gruntów indywidualnych. Powierzchnia ta waha się od $0.9 \%$ we wsi Prymusowa Wola do $66.3 \%$ we wsi Tomaszówek. W 6 wsiach procentowy udział w badanym przedziale wyniósł ponad 50.0\% ogólnej powierzchni gruntów indywidualnych.

\section{Podsumowanie}

Zastosowane narzędzia analiz, którymi dysponują Systemy Informacji Przestrzennej umożliwia bardzo sprawną i wnikliwą analizę struktury przestrzennej pod kątem użytkowania, władania, jak również rozdrobnienia działek. W przypadku gminy Sławno dzięki wykorzystanym narzędziom zaimplementowanym w oprogramowaniu QGIS uzyskano mapy i tabelaryczne zestawienia powierzchni lub liczby działek dla zadanych grup władania, użytkowania lub rozdrobnienia, które pozwoliły na dokładne przeanalizowanie warunków prawno-własnościowych i oraz struktury użytkowej występujących w badanej gminie Sławno.

Jak wynika z przeprowadzonych badań w gminie Sławno rozdrobnienie gruntów gospodarstw indywidualnych jest dość duże, jednak zdecydowanie mniejsze a niżeli we wsiach położonych w południowo-wschodniej Polsce, gdzie działki do 0.10 ha stanowiły aż $34.6 \%$ ogólnej liczby działek, a powierzchnia przez nie zajmowaną (3467.3ha), stanowiła $6.5 \%$ powierzchni badanego terenu [6]. W gminie Sławno działki te zajmowały $22.6 \%$ a ich powierzchnia stanowiła zaledwie $2.8 \%$ ogólnej powierzchni gruntów indywidualnych. Działki o powierzchni większej od 1.01 ha stanowiły aż $9.9 \%$ ogólnej liczby działek, co stanowi $37.1 \%$ ogólnej powierzchni badanego terenu. 
Zastosowanie metod GIS w analizie struktury przestrzennej...

Tabela 4. Rozdrobnienie działek ze względu na ich powierzchnię

Table 4. Fragmentation of plots at intervals of surface

\begin{tabular}{|c|c|c|c|c|c|c|c|c|c|c|c|c|}
\hline \multirow{3}{*}{ Lp. } & \multirow{3}{*}{$\begin{array}{l}\text { Nazwa } \\
\text { obrębu }\end{array}$} & \multirow{3}{*}{$\begin{array}{c}\text { Ogólna po- } \\
\text { wierzchnia } \\
\text { gruntów } \\
\text { gospodarstw } \\
\text { indywidualnych }\end{array}$} & \multicolumn{10}{|c|}{ Przedziały powierzchniowe } \\
\hline & & & \multicolumn{2}{|c|}{$0 \div 0.10 \mathrm{ha}$} & \multicolumn{2}{|c|}{$0.11 \div 0.30$ ha } & \multicolumn{2}{|c|}{$0.31 \div 0.60$ ha } & \multicolumn{2}{|c|}{$0.61 \div 1,00$ ha } & \multicolumn{2}{|c|}{$>1.01$ ha } \\
\hline & & & Pow. & $\%$ & Pow. & $\%$ & Pow. & $\%$ & Pow. & $\%$ & Pow. & $\%$ \\
\hline 1 & Antoninów & 294,5 & 7,3 & 2,5 & 38,1 & 12,9 & 70,8 & 24,1 & 86,2 & 29,3 & 92,0 & 31,2 \\
\hline 2 & Antoniówka & 317,0 & 8,4 & 2,7 & 56,6 & 17,9 & 107,0 & 33,7 & 79,4 & 25,1 & 65,6 & 20,7 \\
\hline 3 & Bratków & 244,6 & 6,7 & 2,7 & 39,1 & 16,0 & 48,8 & 20,0 & 37,8 & 15,4 & 112,2 & 45,9 \\
\hline 4 & Celestynów & 76,3 & 0,7 & 0,9 & 7,1 & 9,3 & 28,3 & 37,0 & 17,4 & 22,9 & 22,8 & 29,8 \\
\hline 5 & Dąbrowa & 269,5 & 8,3 & 3,1 & 55,8 & 20,7 & 72,0 & 26,7 & 83,2 & 30,9 & 50,3 & 18,6 \\
\hline 6 & Dąbrówka & 348,3 & 9,1 & 2,6 & 34,1 & 9,8 & 71,7 & 20,6 & 83,3 & 23,9 & 150,1 & 43,1 \\
\hline 7 & Gawrony & 568,0 & 19,3 & 3,4 & 123,7 & 21,8 & 191,6 & 33,7 & 130,9 & 23,0 & 102,5 & 18,0 \\
\hline 8 & Grążowice & 252,1 & 29,1 & 11,6 & 54,2 & 21,5 & 54,0 & 21,4 & 52,8 & 21,0 & 61,9 & 24,5 \\
\hline 9 & $\begin{array}{l}\text { Kolonia } \\
\text { Grudzień }\end{array}$ & 133,1 & 2,5 & 1,8 & 21,8 & 16,4 & 44,0 & 33,1 & 32,8 & 24,6 & 32,0 & 24,0 \\
\hline 10 & $\begin{array}{l}\text { Grudzień } \\
\text { Las }\end{array}$ & 62,2 & 4,6 & 7,3 & 15,9 & 25,6 & 14,9 & 23,9 & 14,0 & 22,5 & 12,9 & 20,7 \\
\hline 11 & Józefów & 127,4 & 4,1 & 3,2 & 33,2 & 26,0 & 48,3 & 37,9 & 32,9 & 25,8 & 9,0 & 7,0 \\
\hline 12 & Kamień & 447,5 & 6,6 & 1,5 & 54,0 & 12,1 & 107,0 & 23,9 & 99,8 & 22,3 & 180,1 & 40,2 \\
\hline 13 & Kamilówka & 224,0 & 2,6 & 1,2 & 38,3 & 17,1 & 55,0 & 24,6 & 60,8 & 27,2 & 67,2 & 30,0 \\
\hline 14 & Kozenin & 547,0 & 4,2 & 0,8 & 39,0 & 7,1 & 109,6 & 20,0 & 123,1 & 22,5 & 271,2 & 49,6 \\
\hline 15 & Kunice & 623,2 & 13,3 & 2,1 & 83,5 & 13,4 & 135,6 & 21,8 & 149,0 & 23,9 & 241,7 & 38,8 \\
\hline 16 & Ludwinów & 132,7 & 1,4 & 1,1 & 9,6 & 7,3 & 36,0 & 27,1 & 36,7 & 27,6 & 49,0 & 36,9 \\
\hline 17 & Olszewice & 6,6 & 0,3 & 4,6 & 0,9 & 14,0 & 0,0 & 0,0 & 3,6 & 54,4 & 1,8 & 27,0 \\
\hline 18 & Olszowiec & 516,7 & 5,5 & 1,1 & 45,3 & 8,8 & 89,3 & 17,3 & 113,7 & 22,0 & 262,8 & 50,9 \\
\hline 19 & Ostrożyna & 240,8 & 16,3 & 6,8 & 73,8 & 30,6 & 90,4 & 37,5 & 40,9 & 17,0 & 19,4 & 8,1 \\
\hline 20 & Owadów & 148,3 & 19,3 & 13,0 & 52,9 & 35,7 & 35,8 & 24,2 & 18,0 & 12,1 & 22,3 & 15,0 \\
\hline 21 & Popławy & 223,2 & 0,2 & 0,1 & 8,1 & 3,7 & 33,5 & 15,0 & 50,0 & 22,4 & 131,4 & 58,9 \\
\hline 22 & $\begin{array}{c}\text { Prymusowa } \\
\text { Wola }\end{array}$ & 259,9 & 23,1 & 8,9 & 95,8 & 36,9 & 84,3 & 32,4 & 54,4 & 20,9 & 2,4 & 0,9 \\
\hline 23 & $\begin{array}{c}\text { Janków } \\
\text { Psary }\end{array}$ & 407,9 & 15,2 & 3,7 & 86,3 & 21,2 & 122,3 & 30,0 & 91,8 & 22,5 & 92,3 & 22,6 \\
\hline 24 & $\begin{array}{c}\text { Sepno } \\
\text { Radonia }\end{array}$ & 270,8 & 0,3 & 0,1 & 10,9 & 4,0 & 43,7 & 16,1 & 51,7 & 19,1 & 164,2 & 60,6 \\
\hline 25 & Sławno & 391,4 & 9,5 & 2,4 & 56,8 & 14,5 & 79,2 & 20,2 & 74,2 & 19,0 & 171,6 & 43,8 \\
\hline 26 & $\begin{array}{l}\text { Sławno } \\
\text { Kolonia }\end{array}$ & 366,3 & 1,7 & 0,5 & 21,3 & 5,8 & 54,8 & 15,0 & 66,2 & 18,1 & 222,4 & 60,7 \\
\hline 27 & Szadkowice & 134,6 & 4,4 & 3,3 & 34,5 & 25,6 & 36,5 & 27,1 & 39,1 & 29,1 & 20,1 & 14,9 \\
\hline 28 & Tomaszówek & 259,8 & 1,1 & 0,4 & 12,1 & 4,7 & 29,0 & 11,2 & 45,1 & 17,4 & 172,3 & 66,3 \\
\hline 29 & Trojanów & 223,2 & 3,9 & 1,8 & 32,9 & 14,7 & 62,6 & 28,0 & 46,7 & 20,9 & 77,0 & 34,5 \\
\hline 30 & Unewal & 207,0 & 8,6 & 4,2 & 42,9 & 20,7 & 52,2 & 25,2 & 33,8 & 16,3 & 69,5 & 33,6 \\
\hline 31 & Wincentów & 292,0 & 5,2 & 1,8 & 27,9 & 9,6 & 51,3 & 17,6 & 67,6 & 23,2 & 140,0 & 47,9 \\
\hline 32 & Wygnanów & 315,3 & 1,0 & 0,3 & 32,0 & 10,1 & 52,4 & 16,6 & 38,8 & 12,3 & 191,1 & 60,6 \\
\hline 33 & Zachorzów & 505,5 & 18,7 & 3,7 & 79,2 & 15,7 & 114,5 & 22,7 & 108,0 & 21,4 & 185,0 & 36,6 \\
\hline 34 & $\begin{array}{c}\text { Kolonia } \\
\text { Zachorzów }\end{array}$ & 487,6 & 16,9 & 3,5 & 67,2 & 13,8 & 98,2 & 20,1 & 87,1 & 17,9 & 218,3 & 44,8 \\
\hline & Razem: & 9924,5 & 279,5 & 2,8 & 1485,1 & 15,0 & 2324,6 & 23,4 & 2150,8 & 21,7 & 3684,4 & 37,1 \\
\hline
\end{tabular}




\title{
Literatura
}

[1] Leń P.: Sposób określenia pilności potrzeb scalenia i wymiany gruntów. Rozprawa doktorska, Akademia Górniczo-Hutnicza, Kraków, 2013.

[2] Strategia Rozwoju Województwa Łódzkiego na lata 2007-2020.

[3] Szczepanik B. 2005, Scalenia gruntów niezbędnym zabiegiem w procesie przekształcania rolniczej przestrzeni produkcyjnej. Scalenia gruntów podstaw rozwoju obszarów wiejskich rozdrobnionego rolnictwa południowo-wschodniej Polski. Rzeszów 2005.

[4] Bielska A., Leń P., (red), Balawejder M., Bielska A., Gniadek J., Król Ż., Kupidura A., Leń P., Oleniacz G., Sobolewska-Maikulska K., Turek A., 2015. Scalenia gruntów determinantem wielofunkcyjnego rozwoju obszarów wiejskich. WSIE, Rzeszów, 2015.

[5] www.ugslawno.pl/portal.php?aid=120411304547c54e9568f2c, data dostępu 20.07.2015 r.

[6] Leń P. 2010. Analiza rozdrobnienia gruntów indywidualnych na przykładzie powiatu Brzozów. Infrastruktura i Ekologia Terenów Wiejskich, Kraków, Nr 2010/ 01.

\section{THE GIS METHODS APPLICATION IN ANALYSIS OF SPATIAL STRUCTURE OF RURAL AREAS MUNICIPALITY SLAWNO, IN THE DISTRICT OPOCZNO}

\begin{abstract}
S u m m a r y
The aim of the paper is to present the possibilities of using GIS methods in analyzing the spatial structure of rural areas. The study was conducted in 34 villages of the municipality Sławno located in the district of Opoczno, Lodz province. The study was carried out analysis of the structure possession of land, land use, and analysis of land fragmentation of individual farms. The results will determine the status of the spatial structure of rural Polish central.
\end{abstract}

Keywords: agricultural land surveying, land consolidation, spatial structure, GIS

DOI:10.7862/rb.2016.205

Przestano do redakcji: 25.08.2016 r.

Przyjęto do druku: 30.11.2016 r. 